\title{
On the Essence of History
}

\author{
Alexey Malinov \\ Department of Russian philosophy, St. Petersburg State University, 7/9 Universitetskaja naberezhnaja \\ Sankt-Peterburg, 199178, Russia; a.v.malinov@gmail.com
}

\section{Doi:10.5901/mjss.2015.v6n6s5p223}

\begin{abstract}
The purpose of the article is to consider the specificity, or essence of history in its relation to the other sciences, both to the Humanities and natural science. History studies society and human being in the past and in the process of development. It exists on the joint of the past and the present; it connects ontological reality of a fact with the interpretative potential of contemporariness. History gives the opportunity to find sense in the sequence of facts and in the kaleidoscope of events. However, the past is mediated with a historical source, which is always loaded with sense, i.e. preinterpreted. History constitutes the new senses on this basis and by means of interpretation. Thus, the result of the historical research consists in the senses and meanings expressed in a specific way - in the narrative.
\end{abstract}

Keywords: history, sense, society, development, reconstruction, narration

\section{Introduction}

The answer to the question "What is history?" is the most fully understood through history itself. The definition of history can lack versatility, while the history of history shows the essence of history itself in the most adequate way.

The object of studying history is society and man not only in their material but in spiritual displays as well. Here a historian's interest coincides with the research arears of other disciplines: sociology, political science, demography, economy, jurisprudence, art criticism, phycology, anthropology, philosophy, linguistics. However, having a common object, these sciences defer in their subject, i.e., in those specific features and relations between individual and social life, which they study. Thus, sociology researches above all the actual condition of society, its structure and relations and trends of development allowing us to make forecasts about its possible changes. For a long time a social dynamics was identified with history. Political science is mainly focused on the question of power. Economy studies a system of production, distribution and consuming material wealth. Demography studies a composition, structure and mechanisms of reproduction of the population, whereas jurisprudence does the norms regulating people's life. Phycology comprehends both individual and collective human behavior, while the subject of history deals with the past state of society and man.

\section{Purpose, Objectives and Methods}

The purpose of the paper is to consider the specificity, or essence of history in its relation to the other sciences, both to the Humanities and natural science. The problem of the research is to demonstrate the essence, the main content of history, reveal the ratio of history and time, history and meaning, history and language. The method of research is philosophical analysis consisting in deductive knowledge of history as a science, and history as a process.

\section{The Subject of History}

The past is the domain of the historical science. The fact that other sciences resort to the sources and genesis of their subject allows us to speak about a historical dimension in these sciences and that they apply the historical method. From this viewpoint the historical method is universal; it is applied to all the Humanities.

However, history studies society both in its past and in its development. Here history finds the points of contact with natural science, as not only society but nature develops as well, so it is possible to speak about history of nature. Sciences studying phenomena in their development have elaborated qualitative methods for researching society: methods of mathematics in cliomentrics, methods of physics in archeomentrics, methods of heliobiology in historiometrics. The complexity of the subject of history determines its inter-disciplinary character as well.

History has a lot of points of contact with philosophy. Philosophy undertakes attempts of realization of both 
historical being (in ontology of history and in theory of historical process) and in historical cognition (in gnosiology of history and methodology of history). Social philosophy studies social ideals not only in their actual existence but also in the dutiful (utopia), and in the past. Axiology which is a study of values allows us to better understand value content of life and the peculiarities of value judgements in history, while logic explicates the structure of historical discourse on the whole. Esthetics describes the past as an esthetical artifact and fiction. The history of philosophy coinciding with the history of ideas, the history social of thinking, the history of worldviews and the history of science approaches the history nearest of all. At the same time there is an important difference between historiography and the history of philosophy: both a historian and a historian of philosophy approach one and the same plot from different viewpoints, even if it interests them both. A historian pays attention to some facts of a thinker's biography, the circumstances of the creation of the work, the individual outlook of the event, new information and the archive data, even if they don't produce any important information. Otherwise, a historian of philosophy is quite contented with well known facts and sources. It is important for him that an idea, an author's thought or his doctrine will be the most fully presented. If new sources don't change our knowledge about a conception cardinally, they can be neglected. Thus, a historian approaches the subject of his research specifically, while a historian of philosophy does it generically. So, the subject of history is society and man in their past and development.

\section{History and Time}

History differs from the other moral sciences and humanities with temporal modality. However, the past itself together with history can only take place thanks to contemporariness. History implies everything that is not contemporary and devoid of the present. Only the present is true, i.e. authentic and actual being. History is devoid of this immediate certainty and it can be suspected of its authenticity, discredited by falsifications, for example new chronology etc. Where is the border between history and contemporariness? What can be considered history and what has not been able to yet? Every researcher gives his own answers to these questions. Any event the sense of which is exhausted and the consequences of which are obvious enough becomes history. In various epochs the history border had various temporal parameters. Thus, for a long time the upper border of the historical research coincided with the first ages of A.D., i.e., the epoch of formation of Christianity. For example, Bayer G. S. (Bayer, 1728; Bayer, 1729) a German historian who had served at the Academy of sciences in S.-Petersburg limited Russian history with a narration about the Scythians, the Sarmatians and the Cimmerians, i.e., tribes who lived on the territory of Russia in the first ages A.D. When another German historian who also served at the Academy of sciences in St.-Petersburg Schlözer A.L. (Schlözer, 1777) by name went into the medieval history, it caused a sandal in the scientific community. It was rather indecent of a true scientist to go in for medieval history. The nearer political history approached contemporariness, the more it got into contact with a sphere of state secrets and hence was subject to a ban.

At the same time not every past can become history. It is necessary to separate history from non-history inside history itself. Thus, the studying of everyday life of the past was not considered to be a matter worth of historian's attention.

The past is measured off the present, and history is perceived as otherness of the present. The present peers into the past and thus cognizes itself better. History as a knowledge of the past is closely connected with the present, and the connection is mutual. The past is necessary for better knowing and understanding the present which has been growing from the past, rooted in it, whereas the present is necessary for understanding the past as our cognition of history is directed from the present to the past; we project senses, notions, ideas, categories of our present into the past and thus cognize it. The past as it is does not have any interest and value. The past in itself is not available and incognizable. History is the past-for-us.

Cognizing of history is impossible beyond value judgements. The historical evaluation is made with the help of ascribing such predicates as positive, negative, progressive, regressive, a role, a meaning etc. to a phenomenon. The evaluation depends on interests and preferences of both a historian and the social group he belongs to. The fact as an object of historical research does not exist beyond evaluation (Lapteva, 2006, S. 203). We evaluate the past by measuring the present and vice versa we cognize the present on the basis of our knowledge of history. In the last case history judges and evaluates the present as magistra vitae. History chooses and only fixies from the past what is more significant to people and makes sense. It being known that the significance of the past is of two kinds: firstly, this is what was significant, important to people of the epoch studied, and secondly, what is interesting to contemporariness. On the one hand, history is based on facts belonging to the past and on the other, it is grounded in senses which are the property of the present.

Thus, history exists in the joint of the past and the present; it connects ontological reality of fact with interpretational 
potential of contemporariness. History allows us to see the sense in what does not exist any longer, to look into the verge of being, to make already non-existing to be a part of the present comprehended. The borders of sense are the same as the borders of history. History gives the opportunity to see sense in the sequence of facts and kaleidoscope.

\section{History and Sense}

History is differentiated from the majority of moral sciences and humanities with the unavailability of its subject for immediate observation. We admit that history has been existing indeed, that the definite events took place, but their reality is not available to us. A French historian Block M. by name equated a historian to an investigator. He wtote about historians: "We act as an investigator who was not the witness to the crime and is trying to reconstruct a picture of it, or a physicist who is compelled to stay at home because of the flu and is informed about the results of his experiment from a laboratory assistant" (Block, 1973, s. 30). Nevertheless, to continue the analogy one can notice that a historian may not only be an investigator, but also a judge, a public prosecutor and a barrister as well. The source is found between a historian and the past. History is the past mediated with both material and spiritual sources.

However, the source is always loaded with sense and interpreted by its author or several authors. Spiritual sources contain information and the definite sense is implied in them. Material sources were created for the definite purposes, i.e., they also have meaning, make sense for man and contain information as well. Historical reality looms on the ontological horizon of a historian's research. A historian proceeds from a belief in reality of the events described. The ontologicality of history belongs to a field of research axiomatic, it cannot be demonstrated and achieved in the process of research.

Philosophers often complain that the fullness of knowledge about the past cannot be achieved. We shall never know everything about the past; all the facts will never be known. If a historian will only search for facts, his analytical work will never become synthetical. P.Ya. Chaadaev Russian philosopher even assumed that one should not strive for new facts in this situation (Chaadaev, 1991). Any quantity of them will be insufficient from the viewpoint of plenitude of historical reality, that is why a philosopher of history faces a problem of understanding the facts already known (the existing facts give enough material for such comprehension). Another P.Y. Chaadaev's contemporary, minister of National education S.S. Uvarov, used to point out that the amount of historical material and information containing in it had already exceeded analytical and interpretative abilities of an individual researcher by the middle of the XIXth century (Uvarov, 1851). It will not take a researcher's whole life to cover all the diversity of the existing facts. A paradox has formed: on the one hand, there is a cardinal factological incompleteness of history, on the other, there is an informational redundancy of historical material. The inference made by S.S. Uvarov coincided with P.Y. Chaadaev's conclusions: history should not chase for new discoveries but should comprehend and analyze material already existing.

After all, a historian deals with senses and meanings implied in sources. He constitutes new senses by means of interpretation and on their basis. Thus, senses and meanings but only expressed in the narrative are the outcome of a historian's research work.

R.D. Collingwood the English historian and philosopher used to remark that a historian faces a problem not only of reconstructing "how it had been indeed", but also of realizing what it had been (Collingwood, 1946). The latter is the question about sense and essence of history. A historian reveals the fragment of historical being which has sense by means of a notion of event. There is no impassible border between being and sense the same as between Cartesian res cogitans and res extensa. Their unity is fixed in tautological forms of our language. Being is presence of sense, and sense is inseparable from the way it is manifested, i.e., how it exists in being and appears in otherness.

History shows sense nature of being best of all, because sense is always present, it is present fixed by our consciousness in a form of act of sense generating. All the present is sheer sense. There is only sense and various forms of its manifestation in the world. History shows this totality of sense with the help of the fact that sense only exists where there have been no material forms any longer. A historian finds sense in the past, in otherness of the present, hence the presentness of the past, the authentity of history is its sense. Sense is a form of being of history.

The notion of event conceals in itself temporal modality as well. An event is a sense fragment of reality, but it is not compelled to mean a singular moment. A historical event may be prolonged in time and space, may have different degrees of intensity. An event is a sense and thus a qualitative feature of historical being. Event is available to interpretation by means of which its sense is revealed. The possibility of interpretation is implied in the very eidetic structure of event. Reality (presene) of sense can be conveyed as follows: there is sense in everything conceivable for us. The following obversion is true as well: sense is condition of possibility of understanding. The answer to the question "How is the cognition of history (historical being) possible?" implies interpretativeness of the past, presence of sense in it. However, the sense of a historical event is bigger than the moment of historical being which it expresses. The sense of an event covers its consequences as well, so it must exceed the limits of a definite temporal and spatial moment. The 
trace of a historical event can be drawn up to contemporariness. So, an event connects the past and the present by sense.

A historical event reveals another side of history. We state that history takes place, that it studies the progress of society and man. Eventuality of history specifies that history is a discrete process. Periodization of history becomes possible from its discreteness. Event is the result of differentiation; being a sense definiteness, it has its own limits allowing us to discern one from another. Event is a counterpoint of history. The difference of historical events is the difference of their sense. It is also necessary to take into account that sense of history is cleared from otherness and free from a material form. But sense is impossible beyond an expression. Such an expression for history will be an even, which is a sense construct existing by means of language and narration.

\section{History and Language}

It is believed that there are two approaches, two attitudes to the study of history. They are manifested in the history of culture most fully. The first one implies cognition of the past from itself, i.e., by means of notions, ideas and values of the very epoch studied. In this case a historical epoch is perceived as a closed inner integrity. The second one means a cognition of the past from research demands and priorities of contemporariness. Here a historical phenomenon is evaluated from the viewpoint of consequences and results of historical events known to a researcher; the notions and categories of a science which is contemporary to a researcher are used. However, whatever clear the methodological dualism is the questions which language will be used to convey ideas and notions of the past epoch and what the language of the epoch contemporary to a historian of science is left.

Historian uses a natural language, while exact sciences have worked out symbolic languages and employ the formalization of knowledge. Man uses natural language for thinking, experiencing, loving and hating etc. All this is part of historian's language who cannot be absolutely free from sense language wealth.

A low level of abstracting and degree of language formalization with a help of which a historian cognizes the past leads to a doubt in scientific justifiability of history. The value of science is not argued in the contemporary scientifically utilitarian society. And if history is not able to fully formalize its knowledge, it loses the right for possessing the truth. Along with that, not every side of life is available for scientific explanations. Thus, love, for example, is not a science and this fact does not lower its meaning in man's life. To declare love with the help of symbolic language is only possible in the world devoid of qualitative characteristics. Historical research remains qualitative above all.

It explains the peculiarities of notions and categories used by a historian. These notions as a rule are polisemantic (one can even point to polisemantics of the very term history), their meanings are not usually created by an original axiomatics of a theory, but are often guided by the context of a research. They are mainly notions with open volume, which can be added to, and the notions themselves can be additionally defined in accordance with a specificity of research. The notions borrowed from other Humanities which introduce their trail of meanings and interpretations can often be used in history. The historical notions are mostly defined with the help of exemplification, i.e., enumeration of the phenomena, events and processes which are implied in its content and which are relevant to a term or the name of a notion.

Narration is a specific form used by a historian to cognize the world. The cognitive function of narration is not fully understood by contemporary science, while it is the most ancient form of knowledge and defining the world, which is discredited in its epistemological possibilities by the calculating thinking of the Modern age. The competition between calculation and narration has been having a very long history. Calculation is directed to itself; finite truths are only available to it, whereas narration wants another, it has an addressee and is always intended for somebody or something, i.e. it has an objective and strives to exceed its limits. Narration is one of the original meanings of the word history. It is not by chance that a historian's work is completed with narration and it cannot be considered a drawback. The other way round, a historical research, in which a narrative principle is not shown enough, the research mostly consisting of tables and schemes leaves the impression of something unsaid, incompleted and is perceived as a range of material, typologies and specific generalizations demanding further comprehension or qualitative interpretation. Sense reconstruction of the past in the form of narration is a historian's work outcome. Narration is form for realizing sense reconstruction.

\section{Conclusion}

Ranging the best samples of historiography with works of art, narrativeness makes history closer to creativity. Creativity means producing something new, sense filling of being and accumulation of being. What does a historian enrich the world with? What does he introduce to everyday life? A historian fills the present with the value of the past, introduces 
sense profoundness into existing being, adds everyday experience with the experience past ages. No doubt, narration reveals sense perspectives to a historian, dictates him the ways of sense creation, often leads the historian and subjects the research to narrative structures of sense. It is useless to resist them. A historian should aim at using these structures for achieving his purpose, which is understanding the world with man in it. The success of this matter mostly depends on the breadth of a historian's general culture, on the level of commanding languages and even on a literary talent.

\section{Acknowledgements}

The research was carried out within the framework of the Scientific Research Project of SPSU (23.38.328.2015).

\section{References}

Bayer, G.S. (1728). De origine et priscis sedibus Scytharum. Commentarii Academiae Scientiarum imp. Petropolitanae. Ad Annum 1726. T. 1. St. Petersburg, 73-93.

Bayer, G.S. (1729). De Cimmeris. Commentarii Academiae Scientiarum imp. Petropolitanae. Ad Annum 1727. T. 2. St. Petersburg, 419433.

Block, M. (1973). Apologija istorii Apologija istorii ili remeslo istorika [Apology history or the historian's craft]. Moskva: Nauka.

Chaadaev, P.Ya. (1991). Filosoficheskie letters. Complete Works and Selected Letters. Vol. 1. Moscow: "Science".

Collingwood, R.G. (1946). The Idea of History. Oxford: Clarendon Press.

Lapteva, M.P. (2006). Teorija i metodologija istorii. Kurs lekcij [Theory and methodology of history. Lecture course]. Perm: Permskiy Gosudarstvenniy Universitet.

Schlözer, A.L. (1777). Historische Untersuchung über Russlands Reichsgrundgesetze. Gotha.

Uvarov, S.S. (1851). It is moving forward whether historical accuracy? Contemporary. № 1, 121-128. 